\title{
Comparison of two different periods of renal cortical activity ratios in the evaluation of ureteropelvic junction obstruction by dynamic renal scintigraphy
}

\section{Üreteropelvik bileşke darlıklarının dinamik renal sintigrafi ile değerlendirilmesinde iki farklı perioddaki kortikal aktivite oranlarının karşılaştırılması}

\section{Zekiye Hasbek*, Semra Özdemir, Bülent Turgut, Taner Erselcan, Levent Cankorkmaz, Demet Alaygut}

Department of Nuclear Medicine (Assist. Prof. Z. Hasbek, MD, Prof. B. Turgut, MD, Prof. T. Erselcan, MD), Department of Pediatric Surgery (Assist. Prof. L. Cankorkmaz, MD), Department of Pediatric Nephrology (Assist. Prof. D. Alaygut, MD), Cumhuriyet University School of Medicine, TR-58140 Sivas, Department of Nuclear Medicine (Assist. Prof. S. Özdemir, MD), Çanakkale Onsekiz Mart University, School of Medicine, TR-17020 Çanakkale

\begin{abstract}
Aim. The aim of this retrospective study is to investigate whether the renal cortical activity at 1 st and 20th minutes in renal scintigraphy can be used as a following parameter to determine the presence of obstruction in pediatric patients group with ureteropelvic junction obstruction. Method. The consecutive 322 kidney renograms were included in the study. Standardized diuretic renograms were visually classified into three groups as non-obstructive, obstructive and indetermined according to their responses to the diuretic. In addition, the cortical regions of interest (ROI) were drawn manually at 1st and 20th min for each kidney and the cortical counts were obtained. Apart from this, kidneys were divided into three major sub-groups based on clearance half-time $(\mathrm{T} 1 / 2) ; \mathrm{T} 1 / 2<10 \mathrm{~min}$ was defined as non-obstruction, $\mathrm{T} 1 / 2>20 \mathrm{~min}$ as obstruction and T1/2 with a value between 10 and 20 minutes as an indeterminate result. Afterwards visual obstruction patterns and 1st/20th min. cortical activity ratios were compared. Results. When the cortical activity ratios are compared to visual obstructive pattern(nonobstructive, obstructive and indeterminate); on the Tc99m DTPA renograms the cortical activity ratios which were greater than $82.8 \%$ were obstructive, ranging from $59.3 \%$ to $82.8 \%$ were found indeterminate. On the Tc-99m MAG-3 renograms the cortical activity ratios which were greater than $74.2 \%$ were obstructive, ranging from $44.6 \%$ to $74.2 \%$ were found indeterminate. As a result of the comparison of $\mathrm{T} 1 / 2$ parameter with the obstruction patterns of the kidneys, T1/2 was in indeterminate group in $124(41.5 \%)$ out of 299 kidneys visually evaluated as non-obstructive while in $7(2.3 \%)$ kidneys T1/2 was in obstructive group. In 4 (23.5\%) out of 17 kidneys which were visually evaluated as indeterminate, T $1 / 2$ was in normal group, in $5(29.4 \%)$ of them T $1 / 2$ was in indeterminate group and in $8(47.1 \%)$ of the 17 kidneys T1/2 was in obstructive group. Conclusion. We think that the use of $1 \mathrm{st} / 20$ th min. cortical activity ratios on the diuretic renogram are helpful in establishing a diagnosis of obstruction in pediatric patient group.
\end{abstract}

Keywords: Pelviureteric junction obstruction, children, Tc99m-DTPA, Tc99m-MAG3

\section{Özet}

Amaç. Retrospektif olan bu çalışmada amacımız, üreteropelvik bileşkede darlığı olan çocuk hasta grubunda, renal sintigrafilerde, 1 'inci ve 20 'nci dakikalardan elde edilen kortikal aktivite oranının, obstrüksiyonun varlığının belirlenmesinde takip parametresi olarak kullanılabilirliğini araştırmaktır. Yöntem. Çalışmaya toplam 322 renogram dahil edildi. Standart renogram eğrileri diüretiğe verdiği cevaba göre vizüel olarak nonobstrüktif, obstrüktif ve şüpheli olarak sınıflandırıldı. Ayrıca her bir böbrek için 1'inci ve 20'nci dakikalarda kortikal ROI'ler çizildi ve kortikal sayımlar elde edildi. Bunun dışında renogram ile hesaplanan T1/2 10 dakikanın altında olan böbrekler normal, 10-20 dakika indetermine, $>20$ dakika kötü drenaj olarak kabul edildi. 
Obstrüksiyon paternleri ile 1'inci ve 20'nci dakikalardaki kortikal aktivite oranları karşılaştırıldı. Bulgular. Kortikal aktivite sayımlarının oranları ile vizüel olarak belirlenen obstrüktif patern (nonobstrüktif, obstrüktif ve şüpheli) karşılaştırıldığında, Tc-99m DTPA renogramında, 1 'inci/20'nci dak. kortikal aktivite oran1 \%82,8'in üzerinde olan hastalar obstrüktif, \%59,3 ile \%82.8 olan hastalar obstrüksiyon açısından şüpheli olarak bulundu. Tc-99 m MAG-3 ile yapılan sintigrafilerde ise, 1'inci/20'nci dak. kortikal aktivite oranı \%74,2'nin üzerinde olan hastalar obstrüktif, \%44,6 ile \%74,2 olan hastalar obstrüksiyon açısından şüpheli olarak bulundu. T1/2 parametresinin böbreklerin obstrüksiyon paterni ile karşılaştırılması sonucunda; vizüel değerlendirmeye göre non-obstrüktif olan 299 böbreğin 124'ünde (41,5\%) T1/2 indetermine grupta, 7'sinde $(2,3 \%)$ ise $\mathrm{T}^{1} 1 / 2$ obstrüktif gruptayd. Vizüel değerlendirmede şüpheli grupta yer alan 17 böbreğin 4'ünde $(23,5 \%) \mathrm{T}^{1} \frac{1}{2}$ normal grupta, 5'inde $(29,4 \%) \mathrm{T}^{1} 1 / 2$ indetermine grupta ve $8^{\prime}$ 'inde $(47,1 \%) \mathrm{T}^{1} \frac{1}{2}$ obstrüktif grupta yer almaktaydı. Sonuç. Biz çocuk hasta grubunda 1 'inci/20'nci dakika kortikal aktivite oranlarının kullanılmasının da obstrüksiyon tanısının konulmasında yardımcı olduğunu düşünmekteyiz.

Anahtar sözcükler: Üreteopelvik bileşke darliği, çocuklar, Tc99m-DTPA, Tc99m-MAG3

Geliş tarihi/Received: December 02, 2013; Kabul tarihi/Accepted: March 10, 2014

\section{*Corresponding author:}

Dr. Zekiye Hasbek, Nükleer Tıp Anabilim Dalı, Cumhuriyet Üniversitesi Tıp Fakültesi, TR-58140 Sivas. E-mail: hasbekz@yahoo.com

\section{Introduction}

The congenital ureteropelvic junction obstruction (UPJO) is the most common cause of hydronephrosis in children. Up to now surgery was the first option in the management of UPJO, however this approach has changed as a result of the development of imaging techniques $[1,2]$. Congenital UPJO does not represent extrinsic anatomical entity. More often, it is a result of an intrinsic process, such as an aperistaltic segment of the ureter. Recent studies have already showed that spontaneous resolution can be seen in slightly moderate and even severe hydronephrosis in newborns [3].

The certain parameters that can be prognostic indicator of UPJO and that can predict which kidneys are safer to follow-up could not be determined yet. Therefore, it is still a matter of debate when to start surgical operation in UPJO cases and which techniques and parameters should be used to give this decision [4]. Diuretic renography is the most commonly used diagnostic tool to detect functional significance of obstruction [5]. In addition to clinical findings there are some crucial scintigraphic parameters that are used for surgery such as the presence of obstruction by the renogram curve and worsening/deterioration of differential renal function (DRF) in pediatric patients [6].

When the dilatation of collecting renal system is developed in UPJO, the renogram curve shows rising uptake. This slow urinary flow can be accelerated with diuretic application. However, the interpretation of obstruction in patients with poor diuretic response is a major problem. The reason of using quantitative parameters in interpretation of diuretic renogram is to determine the most accurate approach in the patient's treatment decision. A cut-off level which can distinguish between the partial and poor drainage has not been found yet.

On the other hand, the drainage parameters that obtained from renogram after diuretic injection are affected by factors such as patient's hydration and quality of injection. Recently it is recommended to use output efficiency (OE) and normalized residual activity (NORA) parameters in interpretation of renal scintigraphy [7, 8]. Unfortunately these parameters can only be used in new system gamma cameras. Therefore we aimed to investigate whether the renal cortical activity at 1 st/20th min can be used as a following parameter to determine the presence and the degree of obstruction in pediatric patients group with UPJO. 


\section{Material and methods}

We retrospectively reviewed the records of 161 patients (98 girls, 63 boys with a median age: $8 \pm 0 \mathrm{yrs}$, range: 1-17yrs) with the diagnosis of unilateral or bilateral UPJO is suspicious which referred to our institution. The patients with dilated ureter, manifest vesicoureteral reflux, ureteral stasis, ureterovesical obstruction, rotation anomaly and single-kidney were excluded from the study. Also, the patients who were not bolus injectioned were excluded from the study. Maternal or paternal written informed consent was obtained prior to the scintigraphic study.

All children undergoing renography were adequately hydrated with saline solution. Imaging was performed in the supine position under the gamma-camera. Diuretic renograms were obtained with Tc99m -labeled diethylene triaminepenta-acetate (Tc99mDTPA) or Tc99m -labeled mercaptoacetyltriglycine (Tc99m -MAG3). The radiopharmaceutical was given intravenously with an age appropriate dose of radioactivity $(3.7 \mathrm{MBq} / \mathrm{kg})$. The patients were placed in supine position. Bladder catheter is not routinely used in our clinical protocol of pediatric examinations. Images were acquired at 2s/frame for 30 frames and 60s/frame for 29 frames $(64 \times 64$ matrix) with a large field of gamma camera equipped with a low-energy all-purpose parallel-hole collimator (Toshiba ECAM). Intravenous $0.5 \mathrm{mg} / \mathrm{kg}$ of furosemide was administered 20. $\mathrm{min}$ after the radiopharmaceutical injection. Post-micturition images were obtained about 30. min after dynamic study. Regions of interests (ROI) were re-drawn over the kidneys by the same specialist for this study. A perirenal C-type region of background activity was used for background subtraction. Differential renal function values were calculated by integral method (time interval 1-2 $\mathrm{min}$ ) $[9,10]$.

The post-micturition static images were acquired within approximately $30 \mathrm{~min}$ after dynamic renal study. A differential renal function of the kidney of between $45-55 \%$ was defined as normal. The maximum length of the kidneys were measured in the longitudinal and transverse axis on the gamma camera imaging. Size differences up to $1 \mathrm{~cm}$ between left and right kidney was accepted to be symmetrical.

The cortical ROIs were drawn manually at 1 st and 20th min. images for each kidney and the cortical count ratios were obtained. According to diuretic response, visual classification was done in three groups as obstructive, non-obstructive and indetermined [4]. While making visual assessment, dynamic images as well as post-micturition static images were take into account. The kidneys which were observed to perform pelvic drainage spontaneously or after diuretic application in physiological time were considered to be non-obstructive. The kidneys which did not perform pelvic drainage despite the diuretic application during the dynamic study and post-micturition images were considered to be obstructive. Patients with no classification, were considered to be equivocal.

Futhermore clearance half-time ( $\mathrm{T} 1 / 2$ ) of the activity calculated by renogram were used for quantitative clasification of UPJO. Patients are divided into three major subgroups based on $\mathrm{T} 1 / 2$ after the injection of the diuretic $(\mathrm{F}+20)$; as Group 1-T $1 / 2<10$ min was defined as non obstruction, Group 2-T $1 / 2>20$ min as obstruction, Group 3-T $1 / 2$ with a value between 10 and $20 \mathrm{~min}$ as an indeteminate result $[11,12]$. These obstruction patterns are compared with 1st/20th min cortical activity ratios.

Statistical Package for the Social Sciences 15.0 software was used for statistical analysis. The chi-square test, ROC analysis and independent sample t-test were applied to evaluate the statistical significance of the parameters, significance levels were presented as $p$ values. It was assumed that the observed differences were statically significant at the $\mathrm{p} \leq 0.01$ levels. 


\section{Results}

A total of 161 patients (98 female and 63 male,) between 1 month and 17 years of age (median: $8 \pm 0$ years) who had a total of 322 kidney renograms were included in this study. Dynamic renal scintigrapy was performed with Tc99m DTPA in 112 patients and with Tc99m MAG-3 in 49 patients. The stasis were detected in 150 of 224 kidneys whose renograms were obtained by Tc99m DTPA. The statis were detected in 70 of 98 kidneys whose renograms were obtained by Tc99m MAG-3.

While differential renal functions are symmetrical in 142 patients, whereas were asymmetrical in 19 patients. Differential renal function on radionuclide scintigraphy revealed 317 kidneys with $>40 \%$ and 5 kidneys with DRF $<40 \%$. The difference between both kidney sizes were greater than $1 \mathrm{~cm}$ in 4 of 5 patients with DRF $<40 \%$. Also in the same 4 of 5 patients small kidneys had DRF $<40 \%$, other 1 kidney had obstruction. Among 220 patients with UPJ stasis $137(62.3 \%)$ patients had hydronephrosis $(\mathrm{p}<0.01)$ (Table 1).

Table 1. Demographic and scintigraphic characteristics.

\begin{tabular}{|c|c|}
\hline Characteristics & n (\%) \\
\hline Mean age at diagnosis (years) (range) & 1 month and years of age (median: $8 \pm 0 \mathrm{yrs}$ ) \\
\hline \multicolumn{2}{|r|}{ 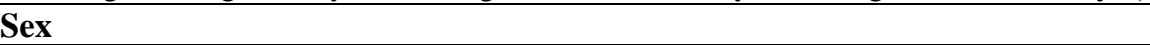 } \\
\hline Female & $98(60.9 \%)$ \\
\hline Male & $63(39.1 \%)$ \\
\hline \multicolumn{2}{|l|}{ Radiopharmaceticals } \\
\hline Tc99m DTPA & $112(69.6 \%)$ \\
\hline Tc99m MAG-3 & $49(30.4 \%)$ \\
\hline \multicolumn{2}{|l|}{ Differential Renal Function Ratio } \\
\hline Symmetric & $142(88.2 \%)$ \\
\hline Asymmetric & $19(11.8 \%)$ \\
\hline
\end{tabular}

When the cortical activity ratios (1st and 20th min) are compared to visual obstructive pattern(non-obstructive, obstructive and indeterminate); on the DTPA renograms the cortical activity ratios which were greater than $82.8 \%$ were obstructive $(100 \%$ specificity, $100 \%$ sensitivity, AUC $=1)$, ranging form $59.3 \%$ to 82.8 were found indeterminate $(92.8 \%$ sensitivity, 92.3\% specificity, AUC=0.958).

On the MAG-3 renograms the cortical activity ratios which were greater than $74.2 \%$ were obstructive (100\% specificity, $100 \%$ sensitivity, AUC=1), ranging from $44.6 \%$ to 74.2 were found indeterminate (95.6\% sensitivity, $100 \%$ specificity, AUC $=0.982$ ).

When 1st/20th min. cortical activity ratio averages of DTPA were compared with MAG-3 by independent sample t-test, the ratios of DTPA were found significantly higher than MAG-3 ( $\mathrm{p}<0.01)$, (Table 2 ). The MAG-3 1st/20th min cortical activity ratio obtained from equivocal/non obstructive group was less than $44.6 \%$, whereas the DTPA 1st/20th min. cortical activity ratio was $59.3 \%$. We already know that the MAG-3 clearance (340 $\mathrm{mL} /$ minute) is greater than the DTPA clearance $(125 \mathrm{~mL} /$ minute $)$, therefore it is compatible to our cortical activity ratios of this radiotracer [13].

When quantitative $\mathrm{T}^{1} / 2$ obstruction parameters were compared with visual obstruction patterns, 124 of 299 (41.5\%) nonobstructive kidney based on visual assessment were in T indeterminate groups, $(2.3 \%) 7$ of 229 were in T1/2obstructive groups. Four $(23.5 \%)$ of 17 kidneys in indeterminate group based on visual assessment were in $\mathrm{T}^{1} / 2$ normal group, 5 $(29.4 \%)$ were in $\mathrm{T} 1 / 2$ indeterminate group, $8(47.1 \%)$ were in $\mathrm{T}^{1} / 2$ obstructive groups (Table $3)$. 
Table 2. When 1st/20th min. cortical activity ratio averages of DTPA were compared with MAG-3 the ratios of DTPA were found significantly higher than MAG-3.

\begin{tabular}{lllll}
\hline & Radiopharmaceutical & n & Mean & p value \\
\hline 1st/20th min. cortical activity ratios & Tc99m DTPA & 224 & $50.56 \pm 12$ & $\mathrm{P}<0.05$ \\
& Tc99m MAG-3 & 98 & $31.40 \pm 28$ & $\mathrm{P}<0.05$ \\
\hline
\end{tabular}

Table 3. According to visual evaluation and $T \frac{1}{2}$ parameter comparison of the pattern of obstruction $(\mathbf{p}<\mathbf{0 . 0 5})$.

\begin{tabular}{llllll}
\hline & & \multicolumn{3}{l}{ Obstructive pattern (according to T $\mathbf{1} / 2$ parameter) } \\
\hline Obstructive & & Normal & Equivocal & Obstructive & Total \\
Pattern(Visual & Non-obstructive & $168(56.2 \%)$ & $124(41.5 \%)$ & $7(2.3 \%)$ & 299 \\
Evaluation) & Obstructive & 0 & $2(33.3 \%)$ & $4(66.7 \%)$ & 6 \\
& Equivocal & $4(23.5 \%)$ & $5(29.4 \%)$ & $8(47.1 \%)$ & 17 \\
\hline Total & & $\mathbf{1 7 2}(\mathbf{5 3 . 4 \% )}$ & $\mathbf{1 3 1}(\mathbf{4 0 . 7 \% )}$ & $\mathbf{1 9}(\mathbf{5 . 9 \%})$ & $\mathbf{3 2 2}$ \\
\hline
\end{tabular}

\section{Discussion}

Common causes of upper tract obstruction include obstructing stones and UPJO. Obstructive nephropathy is a renal dysfunction which develops after uropathy. Congenital UPJO is the most frequent cause of obstructive nephropathy. The first pathophysiologic change in UPJO is the increase in the intrapelvic hydrostatic pressure [14]. Renal parenchyma is tried to be protected by the dilatation of renal pelvis. Hydronephrosis refers to distension and dilatation of the renal pelvis and calyces. It is a mechanism that is developed to protect the kidney from high pressure and renal damage. Although it is frequently observed with obstructions in the upper urinary system, it can also be the result of many non-obstructive factors such as vesicoureteral reflux, dilated extrarenal pelvis or extremely full bladder $[15,16]$.

Urinary obstruction increases the risk of infection and urolithiasis, probably by urinary stagnation [17]. If obstruction is not treated in time, it can cause progressive loss of kidney functions [11]. The prolonged excretion does not always indicate obstruction. In addition to this, renal functions can be reversible by surgical treatment even in the severe hydronephrotic kidneys accompanied with thin renal parenchyma in children [18]. Although there are not any changes in differential kidney functions in partial ureteropelvic obstructions, the functional changes can occur in the kidneys [19]. On the contrary, there might be spontaneous recovery in patients with non-obstructive hydronephrosis. For this reason, watchful-waiting approach is preferred primarily [14]. Radionuclide scintigraphy shows the presence and severity of obstruction as functionally in hydronephrosis cases caused by obstructions in ureteropelvic junctions [3]. Therefore, it is one of the most important imaging methods to be used in the diagnosis and following of UPJO.

Ultrasonography is the preferred screening modality in the evaluation of hydronephrosis, but it doesn't illustrate the cause of UPJO or permit functional evaluation of the kidney. Obstructive hydronephrosis is usually diagnosed by imaging prolonged drainage in diuretic renal scintigraphy [20]. The renogram pattern identified in diuretic scintigraphy is related to the degree of the obstruction and it helps to decide whether a surgical treatment is needed or not [21-24]; because, in UPJO treatment, there are two debatable facts; first the initial management of patients and second the appropriate time of surgical intervention. In dynamic renal scintigraphy, the first finding in hydronephrotic kidneys is the decrease of radiotracer in similar amounts in renal pelvis and collecting system in the area surrounding renal parenchyma. The amount of retained radiotracer is related to the functioning of hydronephrotic kidney [3]. In severe obstructions, the accumulation of radiotracer in dilated renal pelvis is considerably slow compared to normal kidneys. The decrease in DRFs in renograms and/or prolonged renal transit time are important criteria 
used in the demonstration of renal obstruction [25]. The visual evaluation of renogram in renal scintigraphies is a routine and easy technique. However, in UPJO cases where visual evaluation is inadequate in determining of the degree of obstruction, and it is necessary to use quantitative value in the interpretation of those cases.

Many studies have been carried out in order to determine the degree of obstruction qualitatively. Whitaker et al. [26] measured the kidney pressure directly with an invasive technique to evaluate the obstruction. According to this test, the reason of renal damage in obstruction is the increase in renal pressure. However, because the technique was quite invasive, it was abandoned in the diagnosis of UPJO. Another parameter used in the evaluation of obstruction was $T^{1 / 2}$ that calculated by renogram curve. It used to be believed that an early surgery was necessary to prevent urinary system infections in cases where $\mathrm{T}^{1} / 2$ parameter was prolonged in diuretic renography, and that this parameter was helpful in giving the decision of surgery [27]. In our study, $41.5 \%$ of the kidneys were in the indetermined group and $2.3 \%$ were in the obstructive group according to $\mathrm{T} 1 / 2$ parameter although they were classified as non-obstructive by visual evaluation. The $23.5 \%$ of the kidneys which were in the normal group and $47.1 \%$ were in the obstructive group according to $\mathrm{T}^{1} / 2$ parameter although they were in the indetermined group according to visual evaluation.

In recent years, surgical intervention is accepted as a common management when the deterioration of hydronephrosis in unilateral UPJO occurs and when the split function in diuretic scintigraphy is below $40 \%$ [14, 24, 28]. However, in cases like ours especially with bilateral stasis, although the functions decrease, the DRF symmetry does not change. Bilateral cases require more serious follow-up and early surgical treatment is necessary. For this reason, although the use of split function in giving the decision of surgery is appropriate in unilateral UPJ obstructions, it is not appropriate in cases with bilateral stasis. This is because no abnormality in the symmetry of kidney functions can be detected until a severe damage in renal parenchyma develops. Renal retention time is the time when radiotracer stays in tubulus before it is sent to ureters. Transit time in nonobstructive patients with dilatation is longer when compared to normal patients [8,22]. Studies carried out in recent years show that the evaluation of both prolonged cortical transit time and poor kidney washout is a valuable indicator/marker for patients who can benefit from pyeloplasty $[4,29]$. Also in our study, the activity remaining in the kidneys in 20th minute was found over $82.8 \%$ and $74.2 \%$ for Tc99m DTPA and Tc99m MAG-3 respectively and this supports the existence of obstruction. Schlotmann et al. [4] emphasized the predictive role of tissue tracer time as a parameter in their studies by stating that patients who were visually evaluated and have delay in tissue tracer time should be treated whereas the risk is low for patients who are found to be normal in tissue tracer time.

The limitation of our study are the limited number of patients with obstruction and the patients follow-up as it is a retrospective study.

Recently the output efficiency (OE) and normalized residual activity (NORA) parameters are recommended in interpretation of renal scintigraphy [7,8]. NORA is remaininig activity in the kidney at given time. $\mathrm{OE}$ is the amount of tracer which has left the kidney at time " $\mathrm{t}$ " in percent of what the kidney has taken up from the blood [30]. These parameters can quantify the renal drainage and estimate the washout of kidneys independently from differential functions. However, the special software is needed to calculate these parameters [31].

Diuretic renography is the most important technique for functional representation of the presence and severity of uretero pelvic junction obstruction.

In conclusion, although NORA and OE are quite reliable, useful in clinics that have simple gamma camera systems, the 1st/20th min cortical activity ratio may be useful in the diagnosis of renal obstruction. 


\section{References}

1. Koff SA. Requirements for accurately diagnosing chronic partial upper urinary tract obstruction in children with hydronephrosis. Pediatr Radiol 2008; 38: S41-8.

2. Onen A, Jayanthi VR, Koff SA. Long-term followup of prenatally detected severe bilateral newborn hydronephrosis initially managed nonoperatively. J Urol 2002; 168: 1118-20.

3. Treves ST, Harmon WE, Packard AB, Kuruc A. Kidneys in: Treves ST, eds. Pediatric Nuclear Medicine/PET. USA: Springer Science+Business Media 2007: 239-85.

4. Schlotmann A, Clorius JH, Clorius SN. Diuretic renography in hydronephrosis: renal tissue tracer transit predicts functional course and thereby need for surgery. Eur J Nucl Med Mol Imaging 2009; 36: 1665-73.

5. Kiratlı PO, Orhan D, Gedik GK, Tekgül S. Relation between radionuclide imaging and pathologic findings of ureteropelvic junction obstruction in neonatal hydronephrosis. Scand J Urol Nephrol 2008; 42: 249-56.

6. Aktaş GE, İnanır S. Relative renal function with MAG-3 and DMSA in children with unilateral hydronephrosis. Ann Nucl Med 2010; 24: 691-95.

7. Piepsz $A$, Nogarède $C$, Tondeur $M$. Is normalized residual activity a good marker of renal output efficiency? Nucl Med Commun 2011; 32: 824-8.

8. Durand E, Blaufox MD, Britton KE, Carlsen O, Cosgriff P, Fine E, Fleming J, Nimmon C, Piepsz A, Prigent A, Samal M; International Scientific Committee of Radionuclides in Nephrourology (ISCORN). International Scientific Committee of Radionuclides in Nephrourology (ISCORN) consensus on renal transit time measurements.Semin Nucl Med 2008; 38: 82-102.

9. Piepsz A, Ham HR. Pediatric applications of renal nuclear medicine. Semin Nucl Med 2006; 36: 16-35.

10. Taylor AT, Blaufox MD, De Palma D, Dubovsky EV, Erbaş B, Eskild-Jensen A, Frøkiær J, Issa MM, Piepsz A, Prigent A. Guidance document for structured reporting of diuresis renography. Semin Nucl Med 2012; 42: 41-8.

11. Gordon I. Diuretic renography in infants with prenatal unilateral hydronephrosis: An explanation for the controversy about poor drainage. BJU Int 2001; 87: 551-5.

12. Taylor A.T. Kidney. Chapter 7. In: Biersack HJ, Freeman LM, Zuckier LS, Grünwald F (eds). Clinical Nuclear Medicine. Springer; Germany 2007; 172-95.

13. Saha GP. Diagnostic uses of radiopharmaceuticals in Nuclear Medicine. Chapter 13. In: Saha GP (eds). Fundamentals of Nuclear Pharmacy. 5th ed. Springer; USA $2003 ; 247-327$.

14. Alberti C. Congenital ureteropelvic junction obstruction: physiopathology, decoupling of tout court pelvic dilatation-obstruction semantic connection, biomarkers to predict renal damage evolution. Eur Rev Med Pharmacol Sci 2012; 16: 213-9.

15. Piepsz A, Gordon I, Brock J 3rd, Koff S. Round table on the management of renal pelvic dilatation in children. J Pediatr Urol 2009; 5: 437-44.

16. Koff SA. The beneficial and protective effects of hydronephrosisAPMIS Suppl 2003; 109: 7-12.

17. İşlek A, Güven AG, Koyun M, Akman S, Alimoğlu E. Probability of urinary tract infection in infants with ureteropelvic junction obstruction: Is antibacterial prophylaxis really needed? Pediatr Nephrol 2011; 26: 1837-41.

18. Baek M, Park K, Choi H. Long-term outcomes of dismembered pyeloplasty for midline-crossing giant hydronephrosis caused by ureteropelvic junction obstruction in children. Urology 2010; 76: 1463-7.

19. Dissing TH, Eskild-Jensen A, Mikkelsen MM, Pedersen M, Frøkiaer J, Djurhuus JC, Gordon I. Normal differential renal function does not indicate a normal kidney after partial ureteropelvic obstruction and subsequent relief in 2-week-old piglets. Eur J Nucl Med Mol Imaging 2008; 35: 1673-80. 
20. Wang TM, Chang PL, Kao PF, Hsieh ML, Huang ST, Tsui KH. The role of diuretic renography in the evaluation of obstructed hydronephrosis after pediatric pyeloplasty. Chang Gung Med J 2004; 27: 344-50.

21. Rossleigh MA. Renal cortical scintigraphy and diuresis renography in infants and children. J Nucl Med 2001; 42: 91-5.

22. Barron BJ, Kim EE, Lamki LM. Renal Nuclear Medicine. Chapter 42. In: Sandler MP, Coleman RE, Patton JA, Wackers FJTH, Gottschalk A (eds). Diagnostic Nuclear Medicine. 5th ed. Philadelphia: Lippincott Williams \& Wilkins 2003; 865-901.

23. Kaselas C, Papouis G, Grigoriadis G, Klokkaris A, Kaselas V.Pattern of renal function deterioration as a predictive factor of unilateral ureteropelvic junction obstruction treatment. Eur Urol 2007; 51: 551-5.

24. Chertin B, Pollack A, Koulikov D, Rabinowitz R, Hain D, Hadas-Halpren I, Farkas A. Conservative treatment of ureteropelvic junction obstruction in children with antenatal diagnosis of hydronephrosis: Lessons learned after 16 years of follow-up. Eur Urol 2006; 49: 734-8.

25. Piepsz A. The predictive value of the renogram. Eur J Nucl Med Mol Imaging 2009; 36: 1661-4.

26. Whitaker RH. Methods of assessing obstruction in dilated ureters. Br J Urol 1973; 45: 15-22.

27. Ueno S, Suzuki Y, Murakami T, Yokoyama S, Hirakawa H, Tajima T, Makuuchi $\mathrm{H}$. Quantitative analysis of infantile ureteropelvic junction obstruction by diuretic renography. Ann Nucl Med 2001; 15: 131-6.

28. Ross SS, Kardos S, Krill A, Bourland J, Sprague B, Majd M, Pohl HG, Gibbons MD, Belman AB, Rushton HG. Observation of infants with SFU Grades 3-4 hydronephrosis: Worsening drainage with serial diuresis renography indicates surgical intervention and helps prevent loss of renal function. J Pediatr Urol 2011; 7: 266-71.

29. Piepsz A, Tondeur M, Nogarède C, Collier F, Ismaili K, Hall M, Dobbeleir A, Ham H. Can severely impaired cortical transit predict which children with pelviureteric junction stenosis detected antenatally might benefit from pyeloplasty? Nucl Med Commun 2011; 32: 199-205.

30. Gordon I, Piepsz A, Sixt R; Auspices of Paediatric Committee of European Association of Nuclear Medicine. Guidelines for standard and diuretic renogram in children. Eur J Nucl Med Mol Imaging 2011; 38: 1175-88.

31. Zaknun JJ, Rajabi H, Piepsz A, Roca I, Dondi M. The International Atomic Energy Agency software package for the analysis of scintigraphic renal dynamic studies: a tool for the clinician, teacher, and researcher. Semin Nucl Med 2011; 41: 73-80. 